Journal : JMMR (Jurnal Medicoeticolegal dan Manajemen Rumah Sakit), 10 (2): 158-176, August 2021

Website : http://journal.umy.ac.id/index.php/mrs

DOI $\quad:$ https://doi.org/10.18196/jmmr.v10i2.11253

\title{
Instrument for Measuring Patient Safety Culture: Literature Review
}

\author{
Yumna Nur Millati Hanifa ${ }^{1}$, Inge Dhamanti ${ }^{12,3}$ \\ ${ }^{1}$ Correspondence Author : yumna.nur.millati-2017@fkm.unair.ac.id \\ 1Departement of Health Policy and Administration, Faculty of Public Health, Universitas Airlangga \\ ${ }^{2}$ School of Public Health, La Trobe University, Victoria, Australia \\ ${ }^{3}$ Center for Patient Safety Research, Universitas Airlangga, Surabaya, Indonesia
}

\begin{tabular}{l}
\hline I N D E X I N G \\
\hline Keywords: \\
Patient safety \\
culture; \\
Instrument; \\
HSOPSC; \\
MaPSaF; \\
SAQ;
\end{tabular}

Kata kunci:

Budaya keselamatan pasien;

Instrumen;

HSOPSC;

MaPSaF;

$S A Q$;

\begin{abstract}
A B S T R AC T
The implementation of safe and quality care with attention to patient safety, requires organization's effort to create and cultivating patient safety culture. Therefore, measurement of patient safety culture is required and the gauge needs to select the right instrument in order to obtain the desired results. The purpose of this article was to map the instruments used in measuring patient safety culture in healthcare organizations. The method used integrated literature review from various sources of research articles published from 2015 to 2020 . The article included if it was available in full text and open access as well as articles described the instruments of patient safety culture or measurement of patient safety culture using one of the instruments of measurement of patient safety culture. The results of the literature review unravel the findings of three instruments such as HSOPSC (Hospital Survey on Patient Safety Culture), MaPSaF (Manchester Patient Safety Assessment Framework) and SAQ (Safety Attitudes Questionnaire). We concluded all three instruments contained four dimensions of patient safety culture, namely open culture, just culture, reporting culture and learning culture and were widely used to measure patient safety culture in hospitals, primary health facilities and other health facilities.
\end{abstract}

Penyelenggaraan perawatan yang aman dan bermutu dengan memerhatikan keselamatan pasien, memerlukan upaya organisasi untuk menciptakan lingkungan yang mendukung salah satunya dengan membudayakan keselamatan pasien. Oleh karena itu, pengukuran budaya keselamatan pasien diperlukan dan fasilitas kesehatan perlu memilih instrumen yang tepat agar mendapatkan hasil yang diinginkan. Tujuan dari artikel ini yaitu untuk memetakan instrumen yang digunakan dalam pengukuran budaya keselamatan pasien oleh organisasi layanan kesehatan. Metode yang digunakan yaitu penelurusan literature review secara terintegrasi dari berbagai sumber dalam bentuk artikel hasil penelitian yang dipublikasikan dari tahun 2015 sampai 2020. Artikel tersedia dalam bentuk teks lengkap dan open access serta artikel berisi mengenai instrumen budaya keselamatan pasien atau pengukuran budaya keselamatan pasien menggunakan salah satu instrumen pengukuran budaya keselamatan pasien. Hasil literature review mengurai temuan instrumen yang digunakan dalam pengukuran budaya keselamatan pasien. Beberapa jenis instrumen tersebut seperti HSOPSC (Hospital Survey on Patient Safety Culture), MaPSaF (Manchester Patient Safety Assesment Framework) dan SAQ (Safety Attitudes Questionnaire). Dapat disimpulkan bahwa ketiga instrumen tersebut secara umum mengandung empat dimensi budaya keselamatan pasien yaitu open culture, just culture, reporting culture dan learning culture serta merupakan tiga instrumen yang paling banyak digunakan untuk melakukan pengukuran budaya keselamatan pasien di rumah sakit, fasilitas kesehatan primer maupun fasilitas kesehatan lainnya.

(C) 2021 JMMR. All rights reserved

Article history: Received 2021-03-03; Revised 2021-04-15; Accepted 2021-06-11

\section{INTRODUCTION}

The Institute of Medicine (IOM) defines basic patient safety as "freedom from accidental injury" (Institute of Medicine, 2001). According to the Regulation of the Minister of Health of the Republic of Indonesia No. 11 of 2017 concerning patient safety, patient safety is a system that secures patient handling. Currently, health service organizations are required to pay 
attention to patient safety aspects during their activities (Kemenkes RI, 2017). According to Vincent (2008), patient safety is defined as avoidance, prevention and improvement of the results of bad actions (injuries) that come from the health care process (Tutiany et al., 2017). On the other hand, based on the facts according to WHO in 2019, one in ten patients experienced an incident while being hospitalized, and there is evidence that four out of every ten patients suffered an injury in primary and outpatient health services. Therefore, patient safety has become an important aspect in patient care to prevent unwanted events and provide safe and quality care.

In order to carry out safe care and pay attention to patient safety, organizational efforts are needed to create a supportive environment, one of which is by cultivating patient safety. Safety culture is defined as shared values, beliefs, norms and procedures related to patient safety in a health organization (Wang et al., 2017). A positive patient safety culture has been widely associated with increased patient safety efforts in health care (Fujita et al., 2014). According to the ACSQHC, a positive patient safety culture is characterized by strong leadership in promoting and prioritizing safety (ACSQHC, 2017).

Patient safety efforts and patient safety culture in the organization are two things that can simultaneously be applied to achieve patient safety goals. The Institute of Medicine (IOM) states that in an effort to change towards a safe health care system there are important challenges related to patient safety culture (Institute of Medicine, 2001). Within the scope of patient safety culture, the existence of a patient safety incident is seen as an opportunity to improve the quality of care to prevent the recurrence of similar patient safety incidents (Jeong et al., 2020). But some studies, problems regarding patient safety culture are often indicated by repeated incidents or potential incidents. This shows a culture of patient safety that has not been optimal.

Research on patient safety culture is a must for health care organizations. It aims to examine how individual and group values, perceptions, attitudes, competencies and behaviors can determine the commitment, style, and capabilities of a health and safety management organization (Ahdiyana, 2011). Patient safety culture research also serves as a general approach to monitoring patient safety efforts in organizations. In practice, there are several types of patient safety culture measurement instruments that can be used in the study. The selection of measurement instruments of patient safety culture needs to be considered in accordance with the expected results by health care facilities.

Several types of patient safety measurement instruments have their respective dimensions or measurement factors that are different. This suggests that patient safety culture is influenced by more than one dimension or determinant. This proves that a patient safety culture is crucial and needs to be controlled in order to create a patient safety culture that can support patient safety efforts. Efforts that need to be made by institutions related to patient safety can be started by assessing patient safety culture using the help of available instruments. The purpose of this literature review is to map the instruments used in measuring patient safety culture by health care institutions.

\section{RESEARCH METHOD}

The writing of this article uses the type of literature review writing. This type of writing is a method of reviewing the literature on the results of previous research. The use of this 
method allows extensive literature search results so that restrictions or limitations are made in the form of time, place, and the database used to search for reference data literature.

The main data sources used in this literature review were obtained through electronic databases, namely PubMed and Google Scholar. Several keywords were used in the search for articles, namely instrument or tool patient safety culture and safety or patient safety or patient culture or patient safety culture or patient safety climate.

In writing this literature review, several inclusion criteria were determined in data collection. The inclusion criteria are articles published in the range of 2015 to 2020, available in full text and open access as well as selected articles regarding patient safety culture instruments or measuring patient safety culture using one of the patient safety culture measurement instruments. While the exclusion criteria in this study were research articles on patient safety culture in the form of commentary and theoretical.

The research analysis used a narrative literature review approach. The data will be processed for extraction, namely by presenting a table regarding the results of the research in the selected article. Furthermore, reference data in the form of selected articles were analyzed descriptively which were mapped into several types of measurement instruments for patient safety culture. The results of the analysis were presented using a narrative according to the type of instrument found by the researcher and describing some of the characteristics of each known patient safety culture measurement instrument.

\section{RESULT AND DISCUSSION}

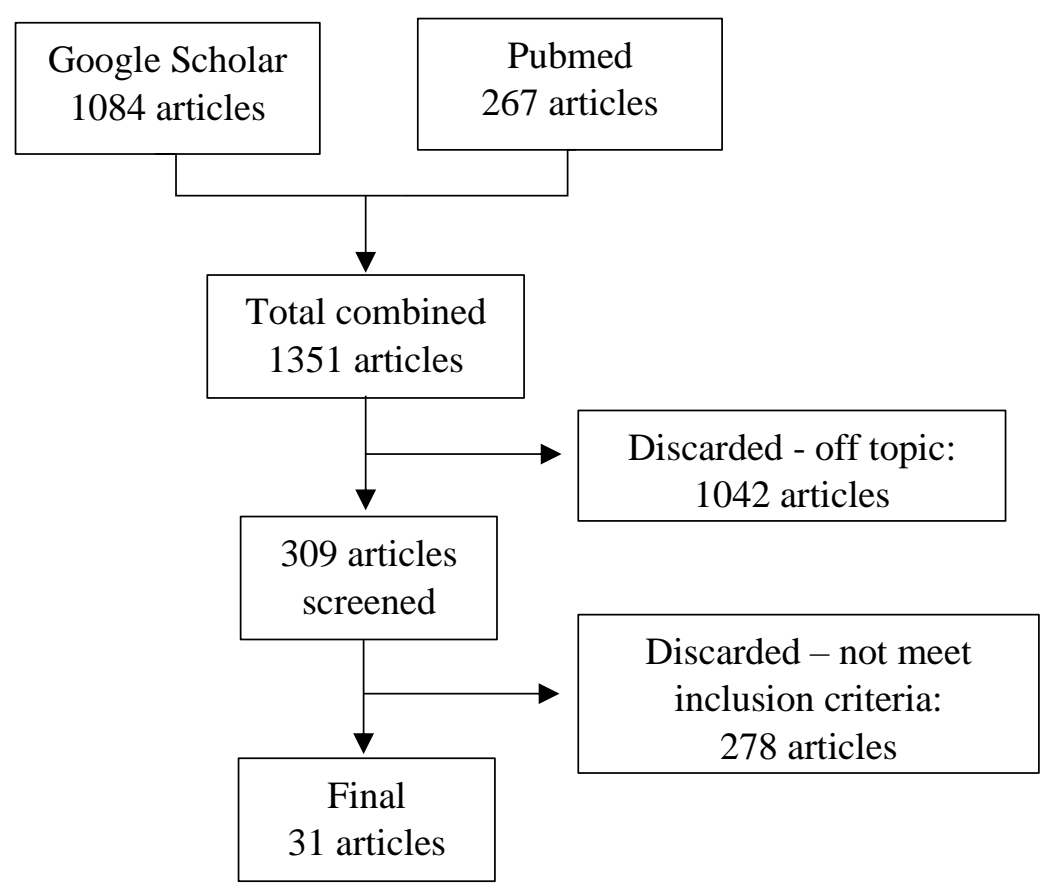

Figure 1. Article Collection

Based on the year of publication in the literature review matrix, it is known that the most found articles were published in 2018, namely 23\% ( $n=7$ articles), 19\% ( $n=6$ articles) published in 2016, 19\% ( $\mathrm{n}=6$ articles) published in 2019, 16\% $(\mathrm{n}=5$ articles) were published 
in 2016 and 10\% ( $n=3$ articles) in 2015 and 13\% $(n=4$ articles) 2020 respectively. (The table of characteristics of the instrument measures the patient's safety culture based on the selected article and literature review matrix attached in the end of this document.) Based on the research design used in the selected article, appears that the research design is $80 \%$ entirely using cross sectional research design. While in other articles using case study research design, explanatory sequential or literature studies.

Based on the research location, it was dominated by research backgrounds in hospitals with 27 studies spread across several countries such as Indonesia, Taiwan, Arab, China, Iran, Germany and others. Total of 4 other studies were located in primary health care conducted in Indonesia, Brazil and the Netherlands. The sample of respondents in the selected research results was dominated by the nursing profession, followed by doctors and other health workers. Based on the patient safety culture measurement instrument, most research activities were carried out using the HSOPSC instrument, namely 18 articles, 9 studies using the SAQ instrument and 4 studies using the MaPSaF instrument.

Based on selected articles, the results of measuring patient safety culture obtained using the Hospital Survey on Patient Safety (HSOPSC) instrument, there are 18 articles that can generally describe what dimensions have been implemented properly or not well by health services. Therefore, the HSOPSC measurement results can provide information on dimensions that require further improvement. The description of the implementation of the dimensions of patient safety culture is generally seen based on the percentage results of each dimension of the HSOPSC instrument. In several studies, the use of HSOPSC was aligned with the conditions in the region, such as the emergence of the German version of HSOPSC, Georgia, Brazil and Spain. The adjustments found in the related article are in terms of utilized language to make them more suitable and understandable in certain regions. In addition to being able to be modified so that it is suitable for use in certain areas, the use of the HSOPSC instrument can be applied in conjunction with other instruments in order to produce more detailed safety information.

Researchers also found 4 articles measuring patient safety culture using the Manchester Patient Safety Culture Assessment Framework (MaPSaF) instrument. The results of measurements using MaPSaF are known to show the level/level of patient safety culture maturity in a health service (Mayeng \& Wolvaardt, 2015). The maturity level is categorized into 4 groups, namely pathological, reactive, bureaucratic, proactive and generative (Agustina, 2018). In addition, the MaPSaF instrument can help determine advantages and disadvantages in terms of patient safety culture. By knowing the level of maturity, as well as the existing advantages/disadvantages, health services can effectively improve or enhance patient safety culture.

Total of 9 articles on the results of research measuring patient safety culture used the Safety Attitude Questionnaire (SAQ) instrument. Based on these results, it is known that the measurement of patient safety culture using SAQ is commonly used to evaluate the application of patient safety culture in health services (Carvalho et al., 2015). In addition to evaluating, measurement using SAQ can provide valuable and relevant information in guiding or recommending intervention actions to improve patient safety culture in a health service (Gambashidze et al., 2020). Just like HSOPSC, SAQ instruments can be developed according to research needs. The Arabic, Chinese, Dutch and Georgian versions of SAQ instruments 
were found in selected articles and were modified for their respective regions. Broadly speaking, the results of adjusting this SAQ instrument are equivalent to the basic context of the SAQ.

Health care facilities need a number of supporting efforts to carry out patient safety, such as the existence of patient safety policies, training, provision of infrastructure and instilling a culture of patient safety for all health service employees. Patient safety culture is a key step towards improving patient safety in hospitals and primary health care facilities (Yarnita, 2019). Health services need to always evaluate and improve the patient safety culture. Therefore it is necessary to measure patient safety culture in a health service in order to know the description and direction of further patient safety improvement (Brahmana et al., 2018).

The analysis of the patient safety culture can be carried out by health services based on the underlying dimensions or conditions of the patient safety culture in the organization. The process of analyzing patient safety culture is facilitated by the existence of several types of instruments such as HSOPSC (Hospital Survey on Patient Safety Culture), MaPSaF (Manchester Patient Safety Assessment Framework) and SAQ (Safety Attitudes Questionnaire).

According to The Health Foundation and ESQH, HSOPSC, MaPSaF and SAQ are three measurement instruments that are often used and recommended for conducting patient safety culture surveys (EUNFP, 2010). The HSOPSC is the primary measurement instrument used by healthcare facilities in the United States (Malone et al., 2014). The advantage of this instrument is that it can be used to assess patient safety culture at the individual, unit or institutional level (AlReshidi et al., 2020). It is not only hospitals, outpatient clinics or primary health facilities that can use the HSOPSC instrument. The European Union Network for Patient Safety (EUNetPaS) in its study states that any health care institution can use this questionnaire to assess patient safety culture in their organization, identify changes in patient safety culture over time and evaluate the impact of patient safety interventions. HSOPSC can be used to assess patient safety culture at the individual, unit, and organizational levels, from managerial to security and cleaning service personnel.

The HSOPSC questionnaire consists of 40 assessment items which are categorized into 12 measurement dimensions. But in 2019, AHRQ re-released the HSOPSC version 2.0 instrument with the addition of 10 measurement dimensions. In a study by Anne Vifladt and Okuyama, it was explained that the 12 dimensions of HSOPSC were divided into three measurement areas, namely dimensions that measure patient safety culture related to work units in the hospital, dimensions to explore aspects of patient safety culture in institutions and outcome dimensions of patient safety culture in hospital (Vifladt et al., 2016). The use of the HSOPSC instrument can be done with other measurement instruments or it can be modified as needed, for example in research by Anke Wagner, conducting an assessment of patient safety culture at Germany University Hospital by developing a questionnaire on the required dimensions according to local conditions (Wagner et al., 2018). Similar to Patrick A. Palmieri's research in 2020, which modified HSOPSC in terms of language according to his research objectives (Palmieri et al., 2020).

HSOPSC is a tool for planning and evaluating patient safety programs and can determine opportunities for improving patient safety culture (Macedo et al., 2016). Meanwhile, MaPSaF is an instrument developed to assist the health care team in reflecting on their organization on the aspects of developing a patient safety culture (Mayeng \& Wolvaardt, 2015) which consists of 10 measurement dimensions and 24 aspects of implementing qualitative measurements. 
This instrument can determine and explore the level of patient safety culture maturity, this is one of the advantages of the MaPSaF instrument. By knowing the maturity level, it can provide better information to health services to improve performance to a higher level.

The MaPSaF instrument describes 4 levels of patient safety culture maturity, namely pathological, reactive, bureaucratic, proactive and generative. The pathological level means that there is no associated system for developing a patient safety culture. Reactive level means that there is a patient safety culture system but is still fragmented for example as part of regulations or for accreditation requirements or only to respond when a patient safety incident occurs, bureaucratic means there is a systematic approach to patient safety, but its implementation is limited to the event of a patient safety incident. The proactive level means that there is a comprehensive approach related to patient safety culture, as well as the implementation of interventions based on data/evidence (evidence-based). The last level is generative, which means that the institution has designed and adopted a patient safety culture as a central part of activities carried out in the institution or is categorized as being integrated with health service objectives so that interventions, evaluations and important actions regarding patient safety are considered.

However, until now, it is still rare to measure patient safety culture using the MaPSaF instrument. The use of the MaPSaF instrument can be done at the individual or team/unit level in health care institutions. Research by John Gammon is one example of the use of the MaPSaF instrument used to identify forms of patient safety culture in isolation units as an effort to prevent infection (Gammon et al., 2019).

The SAQ instrument originated from the FMAQ (The Flight Management Attitude Questionnaire) which is a survey of human factors to measure culture in the aviation industry. SAQ is an instrument that focuses on the safety climate, in this instrument the teams in the organization are asked to describe their attitudes regarding the six dimensions of SAQ. The use of the SAQ instrument is quite extensive, it can be used in several health and non-health institutions. Many countries have used measurements with the SAQ instrument that are modified to the conditions of each country. In addition, the SAQ instrument can also be adjusted specifically to the unit where the safety culture assessment will be carried out, for example the SAQ instrument which is intended for outpatient or primary care units (Robb \& Seddon, 2010). Filling out the SAQ questionnaire is relatively quick and short and can be used as an instrument in evaluating after an intervention is given. However, in some institutions, SAQ is considered too simple so that it is considered inadequate to explain things about the dimensions that exist in the culture being applied.

The similarity of the three patient safety culture instruments, in a study by Arum Astika, states that the three instruments were developed based on the theory of Reason (1997), although if studied further there are advantages and disadvantages of each. In Reason's theory, it contains four dimensions of patient safety culture, namely open culture, just culture, reporting culture and learning culture (Astika \& Dewi, 2016).

Safety Attitudes Questionnaire (SAQ) dan Hospital Survey on Patient Safety Culture (HSOPSC) is the simplest and most practical measuring tool that can be used in measuring patient safety culture and has strong evidence to show an improvement in patient safety culture. These two instruments have also been recommended from several previous research results. 


\section{CONCLUSION}

HSOPSC, MaPSaF, and SAQ are three instruments that are widely used to conduct surveys related to patient safety culture in hospitals, primary health facilities and other health facilities. The three instruments have in common, namely that they were developed based on Reason's theory, which can be used according to organizational conditions. HSOPCS is the most commonly used instrument, consist of 10-dimensional questions and the results illustrate the dimensions that need to be improved. MaPSaF is the only instrument that can show the level of maturity of patient safety culture into five levels namely pathological, reactive, bureaucratic, proactive, and generative. Meanwhile, the SAQ instrument is relatively faster, simpler, and can be used as an instrument in post-intervention evaluation of patient safety culture.

There are a number of other instruments that have been developed, used and commented on by experts but are not directly recommended. This is because there is a tendency for other instruments to emphasize more attitudes, opinions, values, assumptions and various individual beliefs when making measurement. To measure patient safety culture, pay attention to the validity and reliability of the instrument or utilize commonly used instruments such as HSOPSC, SAQ, or MaPSaF.

\section{REFERENCE}

ACSQHC. (2017). National Model Clinical Governance Framework. In NSQHS Standards.

Agustina, D. (2018). Safety Culture Assessment: a Tool for Improving Patient Safety in Hospital. Jurnal Medicoeticolegal Dan Manajemen Rumah Sakit. https://doi.org/10.18196/jmmr.7265

Ahdiyana, M. (2011). DIKTAT - Perilaku Organisasi. Universitas Negeri Yogyakarta.

AlReshidi, A., Farajat, M., Ibrahim, T., Alresheedi, A., Elnefiely, A., \& Alforaih, F. M. (2020). Current Status and Predictors of Patient Safety Culture in Hospitals of Qassim Region, Saudi Arabia. Dr. Sulaiman Al Habib Medical Journal, 2, 76-82. https://doi.org/10.2991/dsahmj.k.200618.001

Astika, A., \& Dewi, A. (2016). Analisis Tingkat Maturitas Budaya Keselamatan Pasien Di Rumah Sakit Terakreditasi Paripurna (Studi Kasus di RS PKU Muhammadiyah Yogyakarta). Repository.Umy.Ac.Id.

Astika Sari, A. (2017). Assessing Patient Safety Culture in the Hospital: a Pilot Study Using a Modified Manchester Patient Safety Framework (MaPSaF). Jurnal Medicoeticolegal Dan Manajemen Rumah Sakit, 6(3), 159-168. https://doi.org/10.18196/jmmr.6141

Brahmana, R. P., Wahyudi, K., \& Hilfi, L. (2018). Perspektif Tenaga Kesehatan: Budaya Keselamatan Pasien Pada Puskesmas Poned Di Kota Bandung. Jurnal Sistem Kesehatan. https://doi.org/10.24198/jsk.v3i3.16985

Carvalho, P. A., Göttems, L. B. D., Pires, M. R. G. M., \& de Oliveira, M. L. C. (2015). Safety culture in the operating room of a public hospital in the perception of healthcare professionals. Revista Latino-Americana de Enfermagem, 23(6), 1041-1048. 


\section{https://doi.org/10.1590/0104-1169.0669.2647}

Fujita, S., Seto, K., Kitazawa, T., Matsumoto, K., \& Hasegawa, T. (2014). Characteristics of unit-level patient safety culture in hospitals in Japan: A cross-sectional study. BMC Health Services Research. https://doi.org/10.1186/s12913-014-0508-2

Gambashidze, N., Hammer, A., Ernstmann, N., \& Manser, T. (2020). Psychometric properties of the Georgian version of the Safety Attitudes Questionnaire: A cross-sectional study. BMJ Open, 10(2), 1-9. https://doi.org/10.1136/bmjopen-2019-034863

Gammon, J., Hunt, J., Williams, S., Daniel, S., Rees, S., \& Matthewson, S. (2019). Infection prevention control and organisational patient safety culture within the context of isolation: Study protocol. BMC Health Services Research, 19(1), 1-8. https://doi.org/10.1186/s12913-019-4126-x

Institute of Medicine. (2001). Shaping the Future; Crossing the quality chasm: a new health system for the 21th century. In Institute of Medicine.

Jeong, H. J., Liao, H. H., Han, S. H., \& Lee, W. C. (2020). An application of item response theory to scoring patient safety culture survey data. International Journal of Environmental Research and Public Health, 17(3), 10-14. https://doi.org/10.3390/ijerph17030854

Kementerian Kesehatan Republik Indonesia. (2017). Peraturan Menteri Kesehatan RI No. 11 Tahun 2017 tentang Keselamatan Pasien. Berita Negara Republik Indonesia.

Macedo, T. R., Rocha, P. K., Tomazoni, A., de Souza, S., Anders, J. C., \& Davis, K. (2016). The culture of patient safety from the perspective of the pediatric emergency nursing team. Revista Da Escola de Enfermagem, 50(5), 756-762. https://doi.org/10.1590/S0080623420160000600007

Malone, O., Dhsc, D., Salisbury, H., \& Dds, D. C. (2014). A Descriptive Comparative Analysis of the Strategies Used by Health-Care Professionals at a Rural Hospital in Jamaica to Promote Patient Safety Article history : 1(4).

Mayeng, L. M., \& Wolvaardt, J. E. (2015). Patient safety culture in a district hospital in South Africa: An issue of quality. Curationis, 38(1), 1-7. https://doi.org/10.4102/curationis.v38i1.1518

Palmieri, P. A., Leyva-Moral, J. M., Camacho-Rodriguez, D. E., Granel-Gimenez, N., Ford, E. W., Mathieson, K. M., \& Leafman, J. S. (2020). Hospital survey on patient safety culture (HSOPSC): A multi-method approach for target-language instrument translation, adaptation, and validation to improve the equivalence of meaning for cross-cultural research. BMC Nursing, 19(1), 1-13. https://doi.org/10.1186/s12912-020-00419-9

Robb, G., \& Seddon, M. (2010). Measuring the safety culture in a hospital setting: A concept whose time has come? In New Zealand Medical Journal.

Safety, Eun. E. U. N. F. P. (2010). Use of Patient Safety Culture Instruments and Recomendations. Europa.

Tutiany, Lindawati, \& Krisanti, P. (2017). Bahan Ajar Keperawatan: Manajemen Keselamatan 
Pasien. Pusat Pendidikan Sumber Daya Manusia Kesehatan Kementerian Kesehatan RI.

Vifladt, A., Simonsen, B. O., Lydersen, S., \& Farup, P. G. (2016). Changes in patient safety culture after restructuring of intensive care units: Two cross-sectional studies. Intensive and Critical Care Nursing, 32, 58-65. https://doi.org/10.1016/j.iccn.2015.06.004

Wagner, A., Michaelis, M., Luntz, E., Wittich, A., Schrappe, M., Lessing, C., \& Rieger, M. A. (2018). Assessment of patient and occupational safety culture in hospitals: Development of a questionnaire with comparable dimensions and results of a feasibility study in a German university hospital. International Journal of Environmental Research and Public Health, 15(12). https://doi.org/10.3390/ijerph15122625

Wang, Y., Coiera, E., Runciman, W., \& Magrabi, F. (2017). Using multiclass classification to automate the identification of patient safety incident reports by type and severity. BMC Medical Informatics and Decision Making, 17(1), 1-12. https://doi.org/10.1186/s12911017-0483-8

Yarnita, Y. (2019). Budaya Keselamatan Pasien Pada Perawat Di Instalasi Perawatan Intensive Rsud Arifin Achmad Provinsi Riau. Jurnal Keperawatan Priority. https://doi.org/10.34012/jukep.v2i2.570 
APPENDIX

Table. 1 Map of patient safety culture measurement instrument based on selected articles

\begin{tabular}{|c|c|c|c|c|c|}
\hline Instrument & $\begin{array}{l}\text { Purpose of using the } \\
\text { instrument }\end{array}$ & $\begin{array}{c}\text { Type of } \\
\text { measurement }\end{array}$ & Respondent & Dimension & $\begin{array}{l}\text { Summary of research results from selected } \\
\text { articles }\end{array}$ \\
\hline $\begin{array}{l}\text { Hospital Survey } \\
\text { on Patient Safety } \\
\text { (HSOPSC) } \\
\text { AHRQ, USA }\end{array}$ & $\begin{array}{l}\text { Review patient safety } \\
\text { cultures, identify changes } \\
\text { in patient safety culture } \\
\text { and evaluate the impact } \\
\text { of patient safety } \\
\text { intervention }\end{array}$ & $\begin{array}{l}\text { Quantitative } \\
\text { (Likert scale) }\end{array}$ & $\begin{array}{l}\text { Individuals, units, } \\
\text { organizations }\end{array}$ & $\begin{array}{l}\text { 1. Communication about error } \\
\text { 2. Communication openness } \\
\text { 3. Handoffs and Information } \\
\text { Exchange } \\
\text { 4. Hospital Management } \\
\text { support for patient safety } \\
\text { 5. Organizational learning- } \\
\text { continuous improvement } \\
\text { 6. Reporting Patient Safety } \\
\text { Events } \\
\text { 7. Response to error } \\
\text { 8. Staffing and Work Pace } \\
\text { 9. Supervisor, manager or } \\
\text { Clinical Leader Support for } \\
\text { Patient Safety } \\
\text { 10. Teamwork }\end{array}$ & $\begin{array}{l}\text { Measurement of patient safety culture using } \\
\text { HSOPSC instruments generally indicates } \\
\text { the condition of applying patient safety } \\
\text { culture in healthcare. Based on } 12 \text { practical } \\
\text { dimensions that should be applied by all } \\
\text { health workers. The results showed } \\
\text { dimensions that have been good or have not } \\
\text { run optimally and based on these, health } \\
\text { services can improve the patient safety } \\
\text { culture in dimensions that have not been } \\
\text { implemented optimally. One of the most } \\
\text { highly rated dimensions is the dimension of } \\
\text { un punitive response to wrongdoing. In } \\
\text { several studies on HSOPSC instruments } \\
\text { studied and developed the instrument by } \\
\text { language adjustment and related region } \\
\text { conditions. This can be seen in several } \\
\text { versions of instruments such as the } \\
\text { German, Georgian, Brazilian and Spanish } \\
\text { versions of the HSOPSC. }\end{array}$ \\
\hline $\begin{array}{l}\text { Manchester } \\
\text { Patient Safety } \\
\text { Culture } \\
\text { Assessment } \\
\text { Framework } \\
\text { (MaPSaF) } \\
\text { Univesity of } \\
\text { Manchester, UK }\end{array}$ & $\begin{array}{l}\text { Assessing the maturity of } \\
\text { patient safety culture in } \\
\text { healthcare organizations }\end{array}$ & Qualitative & $\begin{array}{l}\text { Managerial level, } \\
\text { operational / technical } \\
\text { level (Individual level } \\
\text { or management) }\end{array}$ & $\begin{array}{l}\text { 1. } \begin{array}{l}\text { Commitment to overall } \\
\text { continuous improvement }\end{array} \\
\text { 2. Priority given to patient safety } \\
\text { 3. System errors and individual } \\
\text { responsibility } \\
\text { 4. Recording incidents and best } \\
\text { practice } \\
\text { 5. Evaluating incidents and best } \\
\text { practice }\end{array}$ & $\begin{array}{l}\text { Measurement of patient safety culture using } \\
\text { MaPSaF instruments is recognized to } \\
\text { demonstrate the multidimensional and } \\
\text { dynamic nature of the patient safety culture. } \\
\text { Some studies have revealed that the results } \\
\text { of the cuts allow organizations to assess } \\
\text { progress or improvement in developing a } \\
\text { patient safety culture. The results of } \\
\text { measuring patient safety culture using this }\end{array}$ \\
\hline
\end{tabular}




\begin{tabular}{|c|c|c|c|c|c|}
\hline Instrument & $\begin{array}{l}\text { Purpose of using the } \\
\text { instrument }\end{array}$ & $\begin{array}{c}\text { Type of } \\
\text { measurement }\end{array}$ & Respondent & Dimension & \begin{tabular}{|c|}
$\begin{array}{c}\text { Summary of research results from selected } \\
\text { articles }\end{array}$ \\
\end{tabular} \\
\hline $\begin{array}{l}\text { Safety Attittude } \\
\text { Questionare } \\
\text { (SAQ) } \\
\text { University of } \\
\text { Texas, USA }\end{array}$ & $\begin{array}{l}\text { To measure the safety } \\
\text { climate by the } \\
\text { organization's staff as } \\
\text { well as to know the } \\
\text { perception of staff about } \\
\text { safety. }\end{array}$ & $\begin{array}{l}\text { Quantitative } \\
\text { (Likert scale) }\end{array}$ & $\begin{array}{l}\text { Individuals/groups } \\
\text { representing all } \\
\text { disciplines in } \\
\text { organization }\end{array}$ & $\begin{array}{ll}\text { 1. } & \text { Teamwork climate } \\
\text { 2. } & \text { Safety climate } \\
\text { 3. } & \text { Job satisfaction } \\
\text { 4. } & \text { Stress recognition } \\
\text { 5. } & \text { Work condition } \\
\text { 6. } & \text { Perceptions of unit } \\
& \text { management }\end{array}$ & $\begin{array}{l}\text { SAQ in several studies assesses the } \\
\text { perception of health workers of the patient } \\
\text { safety culture, especially about values, } \\
\text { attitudes, skills, and behaviors that can } \\
\text { determine patient safety culture applied. } \\
\text { Inter-dimensions on SAQ have affected } \\
\text { each other. So health service needs to pay } \\
\text { attention to the dimensions in order to be } \\
\text { applied as a whole. In some research using } \\
\text { SAQ instruments study and develop this } \\
\text { measuring instrument by language } \\
\text { adjustment and related region conditions. } \\
\text { In several versions of instruments such as } \\
\text { the Chinese, Georgian, Arabic versions of } \\
\text { SAQ as well as adjustments to measured } \\
\text { units such as the SAQ-AV (Ambulatory } \\
\text { Version). }\end{array}$ \\
\hline
\end{tabular}


Table.2 Literature Review Matrix

\begin{tabular}{|c|c|c|c|c|c|c|}
\hline No & Researchers & $\begin{array}{c}\text { Research } \\
\text { design }\end{array}$ & Research objectives & $\begin{array}{l}\text { Research locations and } \\
\text { samples }\end{array}$ & $\begin{array}{c}\text { Measurement } \\
\text { instruments }\end{array}$ & Result \\
\hline 1 & $\begin{array}{l}\text { Macedo, Taise } \\
\text { Rocha, et al. } \\
(2016)\end{array}$ & $\begin{array}{l}\text { Quantitative } \\
\text { studies, cross } \\
\text { sectional }\end{array}$ & $\begin{array}{l}\text { Identify patient safet } \\
\text { culture in child } \\
\text { emergencies from the } \\
\text { perspective of a team of } \\
\text { nurses }\end{array}$ & $\begin{array}{l}\text { Three Children's Emergency } \\
\text { units with } 77 \text { nurses as } \\
\text { samples }\end{array}$ & HSOPSC & $\begin{array}{l}\text { The results showed that the patient safety culture } \\
\text { in the unit has not been optimal because there is } \\
\text { a visible cultural gap between the identified } \\
\text { dimensions of both expectations and } \\
\text { management actions in promoting patient safety } \\
\text { with a non-punitive response to errors and } \\
\text { support from management related to patient } \\
\text { safety. But the study found possible dimensions } \\
\text { that could transform and contribute to patient } \\
\text { safety. }\end{array}$ \\
\hline 2 & $\begin{array}{l}\text { Galvao, Taise } \\
\text { Freire, et al (2018) }\end{array}$ & Cross sectional & $\begin{array}{l}\text { Measuring patient safety } \\
\text { culture in university } \\
\text { hospitals }\end{array}$ & $\begin{array}{l}\text { In hospital of university with } \\
\text { sample of } 381 \text { employees }\end{array}$ & HSOPSC & $\begin{array}{l}\text { Generally, patient safety culture is still low } \\
\text { because } 9 \text { out of } 12 \text { measurement dimensions } \\
\text { have low percentage. The dimension of non- } \\
\text { punitive response to error is the dimension with } \\
\text { the lowest percentage of } 18 \% \text { so it is known that } \\
\text { some patient safety incidents are not reported. } \\
\text { Hospitals have an alternative improvement on } \\
\text { the lowest dimensions first. }\end{array}$ \\
\hline 3 & $\begin{array}{l}\text { Carvalho, Paloma } \\
\text { Aparecida, et al. } \\
(2015)\end{array}$ & Cross sectional & $\begin{array}{l}\text { Evaluating health } \\
\text { workers' perceptions of } \\
\text { patient safety culture in } \\
\text { the operating room }\end{array}$ & $\begin{array}{l}\text { In hospital with sample of } \\
226 \text { health workers }\end{array}$ & SAQ & $\begin{array}{l}\text { Health workers' perception of patient safety } \\
\text { culture is still weak. The results showed that the } \\
\text { weakness of the patient safety culture is present in } \\
\text { terms of values, attitudes, skills and behaviors } \\
\text { that determine the safety culture in health } \\
\text { organizations. Therefore, the organization needs } \\
\text { to nurture its employees in order for patient } \\
\text { safety to be optimal. }\end{array}$ \\
\hline 4 & $\begin{array}{l}\text { Souza, Marina } \\
\text { Mazzuco de, et al. } \\
(2019)\end{array}$ & Cross sectional & $\begin{array}{l}\text { Evaluating patient safety } \\
\text { culture in primary health } \\
\text { care }\end{array}$ & $\begin{array}{l}\text { All primary health services in } \\
\text { City X with sample of } \\
\text { managers and } 349 \text { health } \\
\text { workers }\end{array}$ & $\begin{array}{l}\text { SAQ } \\
\text { Ambulatory } \\
\text { version }\end{array}$ & $\begin{array}{l}\text { The safety culture of primary service } \mathrm{X} \text { produces } \\
\text { positive/good value. In order to maintain and } \\
\text { improve the culture of patient safety, research } \\
\text { recommends such as the application of protocols, } \\
\text { training and improved communication. }\end{array}$ \\
\hline
\end{tabular}




\begin{tabular}{|c|c|c|c|c|c|c|}
\hline No & Researchers & $\begin{array}{c}\text { Research } \\
\text { design }\end{array}$ & Research objectives & $\begin{array}{l}\text { Research locations and } \\
\text { samples }\end{array}$ & $\begin{array}{c}\text { Measurement } \\
\text { instruments }\end{array}$ & Result \\
\hline 5 & $\begin{array}{l}\text { Huang, Chih- } \\
\text { Husan } \\
(2018)\end{array}$ & Cross sectional & $\begin{array}{l}\text { Knowing patient safety } \\
\text { perceptions from four } \\
\text { categories of hospital } \\
\text { staff }\end{array}$ & $\begin{array}{l}\text { In hospital with } 588 \\
\text { respondents }\end{array}$ & $\begin{array}{ll}\text { SAQ } & \text { (Chinese } \\
\text { version) } & \end{array}$ & $\begin{array}{l}\text { The perception of patient safety culture in } \\
\text { hospital staff is dominated by positive values. The } \\
\text { results of the measurements on doctors and } \\
\text { administrators, show the dimensions of the safety } \\
\text { climate are strongly correlated with the } \\
\text { dimensions of the teamwork climate and } \\
\text { management perceptions. In nurses, the safety } \\
\text { climate dimension is strongly correlated with the } \\
\text { dimensions of teamwork climate and working } \\
\text { conditions. And on the technician staff, job } \\
\text { satisfaction is strongly related to the dimensions } \\
\text { of the safety climate and working conditions. }\end{array}$ \\
\hline 6 & $\begin{array}{l}\text { Vifladt, Anne, et } \\
\text { al. (2016) }\end{array}$ & Cross sectional & $\begin{array}{l}\text { Comparing the } \\
\text { perceptions in nurses } \\
\text { about patient safety } \\
\text { culture in restructured } \\
\text { and unstructured } \\
\text { intensive care units over } \\
\text { a four-year period. }\end{array}$ & $\begin{array}{l}\text { Six hospitals with a sample of } \\
123 \text { participants }\end{array}$ & HSOPSC & $\begin{array}{l}\text { The results showed that restructuring was } \\
\text { negatively associated with changes in safety } \\
\text { culture, particularly in the dimensions of safety } \\
\text { culture at the care unit level. The most vulnerable } \\
\text { dimensions in restructuring are the dimension of } \\
\text { expectations and actions of managers in } \\
\text { promoting safety, the dimension of teamwork in } \\
\text { the unit, and the staffing dimension. }\end{array}$ \\
\hline 7 & $\begin{array}{l}\text { Gozlu, Kenan et } \\
\text { al. (2016) }\end{array}$ & Cross sectional & $\begin{array}{l}\text { Evaluate patient safety } \\
\text { culture in nurses in JCI- } \\
\text { accredited Turkish } \\
\text { hospitals and compare } \\
\text { them with data (AHRQ). }\end{array}$ & $\begin{array}{l}\text { JCI accredited private } \\
\text { hospital with } 70 \text { nurses as } \\
\text { pastisipan }\end{array}$ & HSOPSC & $\begin{array}{l}\text { The patient safety culture at JCI accredited } \\
\text { hospitals produces a good percentage. The } \\
\text { dimensions of teamwork in units and staffing are } \\
\text { the dimensions with the highest and lowest } \\
\text { positive response rates. The results of the } \\
\text { assessment by nurses showed a good patient safety } \\
\text { culture, one of which was seen from the absence } \\
\text { of incidents over the past } 12 \text { months. }\end{array}$ \\
\hline 8 & $\begin{array}{l}\text { Kiaei, } \\
\text { Mohammad } \\
\begin{array}{l}\text { Zakaria, et al. } \\
(2016)\end{array}\end{array}$ & Cross sectional & $\begin{array}{l}\text { Evaluating the status of } \\
\text { patient safety culture at } \\
\text { three hospitals in Iran }\end{array}$ & $\begin{array}{l}\text { Three hospitals with } 522 \\
\text { health workers as samples }\end{array}$ & HSOPSC & $\begin{array}{l}\text { The results showed a positive response in } 12 \\
\text { dimensions of } 62.9 \% \text {. The learning dimension of } \\
\text { the organization is the dimension that gets the } \\
\text { highest positive response, while Handsoffs }\end{array}$ \\
\hline
\end{tabular}




\begin{tabular}{|c|c|c|c|c|c|c|}
\hline No & Researchers & $\begin{array}{l}\text { Research } \\
\text { design }\end{array}$ & Research objectives & $\begin{array}{l}\text { Research locations and } \\
\text { samples }\end{array}$ & $\begin{array}{c}\text { Measurement } \\
\text { instruments }\end{array}$ & Result \\
\hline & & & & & & $\begin{array}{l}\text { \&Transitions is the dimension with the lowest } \\
\text { response. }\end{array}$ \\
\hline 9 & $\begin{array}{l}\text { AlReshidi, Ayed } \\
\text { et al. (2020) }\end{array}$ & Cross sectional & $\begin{array}{l}\text { Describing the patient } \\
\text { safety culture and factors } \\
\text { believed that contribute } \\
\text { to the condition of the } \\
\text { patient safety culture of } \\
\text { the Hospital Qassim } \\
\text { Region, Saudi Arabia }\end{array}$ & $\begin{array}{l}\text { Hospital in Qassim area with } \\
146 \text { employees as samples }\end{array}$ & HSOPSC & $\begin{array}{l}\text { The patient safety culture at 171assim area } \\
\text { hospitals has not been optimal. Seen from the } \\
\text { results of the measurements identified that there } \\
\text { are four dimensions of patient safety culture that } \\
\text { require improvement, including the dimensions } \\
\text { of cross-unit teamwork, staffing, delivery and } \\
\text { transition, as well as dimensions of un punitive } \\
\text { response to errors. }\end{array}$ \\
\hline 10 & $\begin{array}{l}\text { Davidson, Opal } \\
\text { Malone et al. } \\
(2016)\end{array}$ & Cross sectional & $\begin{array}{l}\text { Compare the strategies } \\
\text { used by healthcare } \\
\text { providers in regional } \\
\text { hospitals in Jamaica with } \\
\text { data published in the } \\
\text { HSOPSC report in the } \\
\text { United States (2014) } \\
\text { specifically on the } \\
\text { promotion of patient } \\
\text { safety. }\end{array}$ & $\begin{array}{l}\text { Regional hospitals in Jamaica } \\
\text { and a total of } 240 \text { healthcare } \\
\text { providers }\end{array}$ & HSOPSC & $\begin{array}{l}\text { The results showed that there are three } \\
\text { dimensions of patient safety culture in regional } \\
\text { hospitals that are superior. But after comparing } \\
\text { the overall positive perception of patient safety } \\
\text { culture in the U.S. compared to Jamaica included } \\
\text { a dimension regarding the promotion of patient } \\
\text { safety. }\end{array}$ \\
\hline 11 & $\begin{array}{l}\text { Yasmi, Yulia dan } \\
\text { Thanraby, } \\
\text { Habullah. (2015) }\end{array}$ & $\begin{array}{l}\text { Explanatoy } \\
\text { sequential }\end{array}$ & $\begin{array}{l}\text { Knowing the patient } \\
\text { safety culture and factors } \\
\text { related to the patient } \\
\text { safety culture at RSKBP. }\end{array}$ & $\begin{array}{l}\text { In hospital with a sample of } \\
115 \text { respondents }\end{array}$ & HSOPSC & $\begin{array}{l}\text { The results showed that the patient safety culture } \\
\text { at RSKBP is still not optimal. Factors related to } \\
\text { the low patient safety culture at RSKBP are found } \\
\text { in several dimensions of patient safety culture, } \\
\text { including the feedback dimension of the incident } \\
\text { report, the culture of not blaming and the culture } \\
\text { of learning. }\end{array}$ \\
\hline 12 & $\begin{array}{l}\text { Brahmana, Reisia } \\
\text { Palmina } \\
\text { (2018) }\end{array}$ & Cross sectional & $\begin{array}{l}\text { Knowing the picture of } \\
\text { patient safety culture at } \\
\text { PONED Health Center } \\
\text { in Bandung }\end{array}$ & $\begin{array}{l}\text { Puskesmas with } 53 \\
\text { puskesmas personnel as a } \\
\text { research sample }\end{array}$ & HSOPSC & $\begin{array}{l}\text { The measurement results showed there were } \\
\text { three indicators of patient safety culture in the } \\
\text { strong category, six indicators in the moderate } \\
\text { category and three indicators that were in the } \\
\text { weak category. So that according to the results are } \\
\text { known } 6 \text { dimensions have not been carried out }\end{array}$ \\
\hline
\end{tabular}




\begin{tabular}{|c|c|c|c|c|c|c|}
\hline No & Researchers & $\begin{array}{c}\text { Research } \\
\text { design }\end{array}$ & Research objectives & $\begin{array}{l}\text { Research locations and } \\
\text { samples }\end{array}$ & $\begin{array}{c}\text { Measurement } \\
\text { instruments }\end{array}$ & Result \\
\hline & & & & & & $\begin{array}{l}\text { optimally and need to be improved. Research } \\
\text { suggests the need for appropriate measuring } \\
\text { instruments to assess patient safety culture in } \\
\text { health centers or other primary services. }\end{array}$ \\
\hline 13 & $\begin{array}{l}\text { Yarnita, Yeni dan } \\
\text { Maswarni. (2019) }\end{array}$ & $\begin{array}{l}\text { Descriptive } \\
\text { studies }\end{array}$ & $\begin{array}{l}\text { Knowing about patient } \\
\text { safety culture in nurses at } \\
\text { the Intensive Care } \\
\text { Installation of Arifin } \\
\text { Achmad Riau Hospital }\end{array}$ & $\begin{array}{l}\text { In hospital with a sample of } \\
63 \text { nurses }\end{array}$ & HSOPSC & $\begin{array}{l}\text { The results proved that the overall dimensions } \\
\text { received a percentage of } 56.3 \% \text { which falls into } \\
\text { the negative category, and } 43.8 \% \text { of the } \\
\text { dimensions of patient safety culture fall into the } \\
\text { positive category. So it is necessary to organize an } \\
\text { improvement program related to the culture of } \\
\text { patient safety. }\end{array}$ \\
\hline 14 & $\begin{array}{l}\text { Syam, Nur } \\
\text { Syarianingsih. } \\
(2017)\end{array}$ & $\begin{array}{l}\text { Quantifiable } \\
\text { method, case } \\
\text { study approach }\end{array}$ & $\begin{array}{l}\text { Knowing the } \\
\text { impelementation of } \\
\text { patient safety culture by } \\
\text { nurses }\end{array}$ & $\begin{array}{l}\text { In hospital with } 141 \text { nurses as } \\
\text { samples }\end{array}$ & HSOPSC & $\begin{array}{l}\text { The results showed that most dimensions of } \\
\text { assessment of patient safety culture received a } \\
\text { positive response. There is only one dimension } \\
\text { responded negatively which is the nonpunitive } \\
\text { response dimension. So in general, the overall } \\
\text { application of the patient's health culture has } \\
\text { gone well. }\end{array}$ \\
\hline 15 & $\begin{array}{l}\text { Suranto, Dwi dkk. } \\
(2020)\end{array}$ & Cross sectional & $\begin{array}{l}\text { Analyzing patient safety } \\
\text { culture in health workers } \\
\text { at RSUD dr. Soediran } \\
\text { Mangun Sumarso, } \\
\text { Wonogiri. }\end{array}$ & In hospital with 228 samples & HSOPSC & $\begin{array}{l}\text { The measurement results showed that the patient } \\
\text { safety culture was well categorized. It is seen that } \\
\text { in } 9 \text { out of } 12 \text { dimensions of the patient safety } \\
\text { culture has a moderate to good percentage. It is } \\
\text { also known that there have been no incidents of } \\
\text { patient safety incidents in the last } 12 \text { months at } \\
\text { the hospital. }\end{array}$ \\
\hline 16 & $\begin{array}{l}\text { Fassarella, Cintia } \\
\text { Silva et al. (2018) }\end{array}$ & Cross sectional & $\begin{array}{l}\text { Comparing the } \\
\text { understanding about } \\
\text { patient safety culture } \\
\text { based on evaluation of } \\
\text { nurses at University } \\
\text { Hospitals in Brazil and } \\
\text { Portugal }\end{array}$ & $\begin{array}{l}\text { In hospital with } 762 \text { hospital } \\
\text { nurses as samples }\end{array}$ & HSOPSC & $\begin{array}{l}\text { The results showed that } 7 \text { out of } 12 \text { dimensions } \\
\text { of patient safety culture showed significant } \\
\text { differences between hospital nurses. The } \\
\text { dimension that has the highest difference is the } \\
\text { management support dimension in patient safety. } \\
\text { This supports hospital manager studies, to make }\end{array}$ \\
\hline
\end{tabular}




\begin{tabular}{|c|c|c|c|c|c|c|}
\hline No & Researchers & $\begin{array}{l}\text { Research } \\
\text { design }\end{array}$ & Research objectives & $\begin{array}{c}\begin{array}{c}\text { Research locations and } \\
\text { samples }\end{array} \\
\end{array}$ & $\begin{array}{c}\text { Measurement } \\
\text { instruments }\end{array}$ & Result \\
\hline & & & & & & $\begin{array}{l}\text { ongoing improvements and improvements in } \\
\text { patient safety culture related to research findings. }\end{array}$ \\
\hline 17 & $\begin{array}{l}\text { Agustina, Dewi. } \\
(2018)\end{array}$ & Cross sectional & $\begin{array}{l}\text { Assessing patient safety } \\
\text { culture at X Hospital, } \\
\text { Palembang }\end{array}$ & $\begin{array}{l}\text { In hospital with a sample of } \\
59 \text { health workers }\end{array}$ & $\mathrm{MaPSaF}$ & $\begin{array}{l}\text { The assessment implements patient safety culture } \\
\text { at 'X' Hospital Palembang according to the } \\
\text { assessment level on MaPSaF instruments at } 70 \% \\
\text { at proactive level, } 20 \% \text { at generative level, and } \\
\text { also } 10 \% \text { at bureaucratic level. So that it is known } \\
\text { as a whole, the culture of patient safety is } \\
\text { dominant at the proactive level, but it still needs } \\
\text { improvement to the generative level such as by } \\
\text { raising awareness, good cooperation, and } \\
\text { responsibility related to the importance of patient } \\
\text { safety culture. }\end{array}$ \\
\hline 18 & $\begin{array}{l}\text { Gammon, John et } \\
\text { al. (2019) }\end{array}$ & $\begin{array}{l}\text { Qualitative } \\
\text { studies, case } \\
\text { studies }\end{array}$ & $\begin{array}{l}\text { Proving the relationship } \\
\text { between patient safety } \\
\text { culture and officer } \\
\text { involvement with IPC } \\
\text { principles and strategies } \\
\text { in isolation rooms. }\end{array}$ & $\begin{array}{l}\text { In hospital with } 40 \\
\text { respondents }\end{array}$ & $\mathrm{MaPSaF}$ & $\begin{array}{l}\text { This study tries to understand the perception of } \\
\text { officers in isolation rooms regarding IPC, how to } \\
\text { promote IPC, how teams of officers respond if } \\
\text { IPC is out of control. These are considered to be } \\
\text { related to the standard of application of patient } \\
\text { safety culture in preventing incidents of patient } \\
\text { safety incidents, especially in the case of } \\
\text { transmission of cases of infection in hospitals. }\end{array}$ \\
\hline 19 & $\begin{array}{l}\text { Astika, } \quad \text { Arum. } \\
(2017)\end{array}$ & $\begin{array}{l}\text { Qualitative } \\
\text { approach, } \\
\text { literature } \\
\text { studies }\end{array}$ & $\begin{array}{l}\text { Modify and define the } \\
\text { dimensions and themes } \\
\text { of patient safety culture } \\
\text { tools with MaPSaF. }\end{array}$ & $\begin{array}{l}\text { In a hospital with } 3 \text { expert } \\
\text { officers to assess the } \\
\text { measurement of patient } \\
\text { safety culture }\end{array}$ & $\mathrm{MaPSaF}$ & $\begin{array}{l}\text { In this study MaPSaF recognized to be able to } \\
\text { demonstrate the multidimensional and dynamic } \\
\text { nature of the patient safety culture as well as allow } \\
\text { organizations to assess progress or improvement } \\
\text { in developing a patient safety culture. The results } \\
\text { also revealed that this tool can help determine the } \\
\text { strengths and weaknesses of hospitals so that they } \\
\text { can be followed up in order to improve the } \\
\text { culture of patient safety in hospitals effectively. }\end{array}$ \\
\hline 20 & $\begin{array}{l}\text { Mayeng, Lorraine } \\
\mathrm{M} \text { and Wolvaardt, }\end{array}$ & Cross sectional & $\begin{array}{l}\text { Identify and analyze } \\
\text { factors that affecting }\end{array}$ & $\begin{array}{l}\text { In hospital with } 61 \text { research } \\
\text { samples }\end{array}$ & $\mathrm{MaPSaF}$ & $\begin{array}{l}\text { The patient safety culture at the hospital has been } \\
\text { well implemented. But especially among doctors } \\
\text { there is a negative perception of the culture of }\end{array}$ \\
\hline
\end{tabular}




\begin{tabular}{|c|c|c|c|c|c|c|}
\hline No & Researchers & $\begin{array}{c}\text { Research } \\
\text { design }\end{array}$ & Research objectives & $\begin{array}{l}\text { Research locations and } \\
\text { samples }\end{array}$ & $\begin{array}{c}\text { Measurement } \\
\text { instruments }\end{array}$ & Result \\
\hline & $\begin{array}{l}\text { Jacqueline } \quad \text { E. } \\
(2015)\end{array}$ & & $\begin{array}{l}\text { patient safety culture } \\
\text { using MaFSaF. }\end{array}$ & & & $\begin{array}{l}\text { patient safety. The shortcomings identified and } \\
\text { aimed at managers provide a practical mandate to } \\
\text { implement changing quality of patient safety } \\
\text { culture. }\end{array}$ \\
\hline 21 & $\begin{array}{l}\text { Wami, Suntayehu } \\
\text { Daba, et al. (2016) }\end{array}$ & Cross sectional & $\begin{array}{l}\text { Assess patient safety } \\
\text { culture and the factors } \\
\text { that influence Hospital X }\end{array}$ & $\begin{array}{l}\text { Four hospitals with } 637 \\
\text { people as research samples }\end{array}$ & HSOPSC & $\begin{array}{l}\text { In general, the implementation of patient safety } \\
\text { culture in four hospitals is still low ( } 46.7 \%) \text {. } \\
\text { Results from interviews in the study showed } \\
\text { incident reporting, resources, attitudes of health } \\
\text { workers and patient engagement as important } \\
\text { factors that affect the culture of patient safety, but } \\
\text { not all have gone optimally. }\end{array}$ \\
\hline 22 & $\begin{array}{l}\text { Buhari, } \quad \text { Basok. } \\
\text { (2019) }\end{array}$ & Cross sectional & $\begin{array}{l}\text { Identifying differences in } \\
\text { patient safety culture of } \\
\text { Government and Private } \\
\text { Hospitals in Jambi City }\end{array}$ & $\begin{array}{l}\text { Government and private } \\
\text { hospitals with } 305 \text { nurses as } \\
\text { samples }\end{array}$ & SAQ & $\begin{array}{l}\text { According to the results of the study, there are } \\
\text { differences in safety culture in the dimensions of } \\
\text { teamwork climate, safety climate, job satisfaction, } \\
\text { stress and work environment between } \\
\text { government and private hospitals, but there is no } \\
\text { difference in patient safety culture in the } \\
\text { dimension of perception towards management } \\
\text { between government and private hospitals. } \\
\text { Furthermore, hospitals can learn each other's. }\end{array}$ \\
\hline 23 & $\begin{array}{l}\text { Jiang, Kexin, et al. } \\
\text { (2019) }\end{array}$ & Cross sectional & $\begin{array}{l}\text { Assessing patient safety } \\
\text { culture in a hospital in } \\
\text { China and explore the } \\
\text { cultural implications and } \\
\text { practices of patient safety } \\
\text { through the perspective } \\
\text { of healthcare workers. }\end{array}$ & $\begin{array}{l}\text { In hospital with } 665 \text { hospital } \\
\text { staff as samples }\end{array}$ & SAQ & $\begin{array}{l}\text { The patient safety culture is going well but } \\
\text { improvements are needed. The results showed in } \\
\text { the dimension of job satisfaction as the highest } \\
\text { dimension among the other five dimensions of } \\
\text { SAQ, followed by teamwork climate, working } \\
\text { conditions, and the introduction of stress } \\
\text { (lowest). This can be used as preliminary data in } \\
\text { drafting policies related to patient safety. }\end{array}$ \\
\hline 24 & $\begin{array}{l}\text { Gambashidze, } \\
\text { Nikoloz, et al. } \\
(2017)\end{array}$ & Cross sectional & $\begin{array}{l}\text { Study the characteristics } \\
\text { of patient safety culture } \\
\text { measurement using the } \\
\text { German version of }\end{array}$ & $\begin{array}{l}\text { Two University Hospitals } \\
\text { with samples of } 974 \text { health } \\
\text { workers. }\end{array}$ & $\begin{array}{l}\text { HSOPSC-D } \\
\text { (German version) }\end{array}$ & $\begin{array}{l}\text { Characteristic test results in HSOPSC-D } \\
\text { measurements with other versions indicate that } \\
\text { there are } 8 \text { relatively stable and 4-dimensional } \\
\text { dimensions requiring further improvement. But }\end{array}$ \\
\hline
\end{tabular}




\begin{tabular}{|c|c|c|c|c|c|c|}
\hline No & Researchers & $\begin{array}{c}\text { Research } \\
\text { design }\end{array}$ & Research objectives & $\begin{array}{l}\text { Research locations and } \\
\text { samples }\end{array}$ & $\begin{array}{c}\text { Measurement } \\
\text { instruments }\end{array}$ & Result \\
\hline & & & $\begin{array}{l}\text { HSOPSC and compare } \\
\text { between dimensions with } \\
\text { other versions to } \\
\text { determine the feasibility } \\
\text { of cross-border use. }\end{array}$ & & & $\begin{array}{l}\text { in general, HSOPSC-D can be accepted and used. } \\
\text { However, cross-border dimension comparisons } \\
\text { will show limitations so it is necessary to } \\
\text { understand the scope of measurements. }\end{array}$ \\
\hline 25 & $\begin{array}{lrr}\text { Patrick, } & \text { A } \\
\text { Palmieri et al. } \\
(2020)\end{array}$ & $\begin{array}{l}\text { Quantitative } \\
\text { and qualitative } \\
\text { studies (mix } \\
\text { method) }\end{array}$ & $\begin{array}{l}\text { Develop Peru version of } \\
\text { HSOPSC instrument so } \\
\text { that it can be used } \\
\text { according to local culture } \\
\text { and conditions. }\end{array}$ & $\begin{array}{l}\text { In hospital with } 16 \text { study } \\
\text { participants }\end{array}$ & HSOPSC & $\begin{array}{l}\text { The results of the very Peruvian HSOPSC } \\
\text { development test are different from the original } \\
\text { instrument but the resulting assessment is } \\
\text { equivalent to the HSOPSC concept. This study } \\
\text { conducts language clarity development and } \\
\text { testing with assessment reliability. Initially } \\
\text { identified as many as } 37 \text { problems and eliminated } \\
\text { into } 4 \text { problems. So at the end of the study, there } \\
\text { was } 1 \text { of } 12 \text { dimensions that had low test results. }\end{array}$ \\
\hline 26 & $\begin{array}{l}\text { Gambashidze, } \\
\text { Nikoloz, et al. } \\
(2017)\end{array}$ & Cross sectional & $\begin{array}{l}\text { Study the characteristics } \\
\text { of measuring patient } \\
\text { safety culture using the } \\
\text { Georgian version of } \\
\text { HSOPSC }\end{array}$ & $\begin{array}{l}\text { Three hospitals with samples } \\
\text { of } 579 \text { hospital employees }\end{array}$ & HSOPSC-GE & $\begin{array}{l}\text { HSOPSC-GE as a whole has not been able to } \\
\text { represent the basic concept of HSOPSC. On } \\
\text { some dimensions it shows acceptable consistency. } \\
\text { However, the overall result appears to be an item } \\
\text { bias that does not fit the original concept. That } \\
\text { way, researchers gain insight into how pasie safety } \\
\text { culture is in Georgian homes. }\end{array}$ \\
\hline 27 & $\begin{array}{l}\text { Elsous, Aymen et } \\
\text { al. (2017) }\end{array}$ & Cross sectional & $\begin{array}{l}\text { Assessing the reliability } \\
\text { and validity of the Arabic } \\
\text { version of SAQ in } \\
\text { Palestinian hospitals }\end{array}$ & $\begin{array}{l}\text { Four hospitals in the Gaza } \\
\text { Strip with } 370 \text { doctors and } \\
\text { nurses as samples }\end{array}$ & $\begin{array}{l}\text { SAQ } \\
\text { version) }\end{array}$ & $\begin{array}{l}\text { The Arabic version of the SAQ instrument is } \\
\text { considered valid and reliable and shows } \\
\text { satisfactory results on all six dimensions of the } \\
\text { SAQ. The instrument is considered promising to } \\
\text { be a good tool used to assess the safety culture in } \\
\text { Palestinian hospitals. }\end{array}$ \\
\hline 28 & $\begin{array}{l}\text { Smits, Marleen et } \\
\text { al. (2017) }\end{array}$ & Cross sectional & $\begin{array}{l}\text { Checking basic factors } \\
\text { and Dutch-language } \\
\text { SAQ-AV psychometry in } \\
\text { primary care services } \\
\text { outside of business hours }\end{array}$ & $\begin{array}{l}\text { Primary care provider with } \\
853 \text { health workers as a } \\
\text { sample }\end{array}$ & $\begin{array}{l}\text { SAQ } \\
\text { Ambulatory } \\
\text { version }\end{array}$ & $\begin{array}{l}\text { SAQ-AV in Dutch has five factors, which are } \\
\text { considered to be a reliable tool to measure patient } \\
\text { safety culture and can guide quality improvement } \\
\text { interventions in primary care services, especially } \\
\text { in terms of patient safety based on the results } \\
\text { obtained in the study. }\end{array}$ \\
\hline
\end{tabular}




\begin{tabular}{|c|c|c|c|c|c|c|}
\hline No & Researchers & $\begin{array}{c}\text { Research } \\
\text { design }\end{array}$ & Research objectives & $\begin{array}{l}\text { Research locations and } \\
\text { samples }\end{array}$ & $\begin{array}{c}\text { Measurement } \\
\text { instruments }\end{array}$ & Result \\
\hline 29 & $\begin{array}{l}\text { Gambashidze, } \\
\text { Nikoloz et al. } \\
(2019)\end{array}$ & Cross sectional & $\begin{array}{l}\text { Studying the } \\
\text { characteristics of patient } \\
\text { safety culture } \\
\text { measurement } \\
\text { instruments using the } \\
\text { Georgian version of SAQ }\end{array}$ & $\begin{array}{l}\text { Three hospitals with samples } \\
\text { of } 305 \text { employees }\end{array}$ & $\begin{array}{ll}\text { SAQ } & \text { Georgian } \\
\text { version } & \end{array}$ & $\begin{array}{l}\text { The Georgian version of the SAQ instrument } \\
\text { proved acceptable on its territory. The test results } \\
\text { showed good consistency and validity of the } \\
\text { construct with the basic concept of SAQ. These } \\
\text { results, as a whole, can provide valuable and } \\
\text { relevant information for the advancement of } \\
\text { patient safety culture at Georgia Hospitals. }\end{array}$ \\
\hline 30 & $\begin{array}{l}\text { Wagner, Anke, et } \\
\text { al. (2018) }\end{array}$ & Cross sectional & $\begin{array}{l}\text { Developing the } \\
\text { questionnaires measuring } \\
\text { patient safety culture and } \\
\text { occupational safety } \\
\text { culture at University } \\
\text { Hospital }\end{array}$ & $\begin{array}{l}\text { University Hospital with } 581 \\
\text { employees as samples }\end{array}$ & HSOPSC & $\begin{array}{l}\text { The research developed and implemented a joint } \\
\text { assessment between the PSC and the OSC. It is } \\
\text { considered worthy to be applied. A joint } \\
\text { assessment is carried out at a major hospital and } \\
\text { the results are a promising approach and can be } \\
\text { recommended for further study. }\end{array}$ \\
\hline 31 & $\begin{array}{l}\text { Losada, Leticia, et } \\
\text { al (2020) }\end{array}$ & $\begin{array}{l}\text { Observational } \\
\text { cross sectional } \\
\text { study }\end{array}$ & $\begin{array}{l}\text { To evaluate the culture of } \\
\text { patient safety in Primary } \\
\text { and Home Care Services } \\
\text { and to verify if there are } \\
\text { relationships between the } \\
\text { SAQ domains and the } \\
\text { variables gender, type of } \\
\text { service (primary care and } \\
\text { home care), and years of } \\
\text { professional experience }\end{array}$ & $\begin{array}{l}147 \text { professionals from nine } \\
\text { district linked to the Home } \\
\text { Care Program and six } \\
\text { primary health care units }\end{array}$ & SAQ & $\begin{array}{l}\text { Safety culture evaluation was better in the home } \\
\text { care service when compared to the primary health } \\
\text { care service. Men who have worked for several } \\
\text { years have a better patient safety culture. } \\
\text { Appropriate for managers to promote the culture } \\
\text { of patient safety in these services, based on the } \\
\text { awareness of professionals of the factors that can } \\
\text { in. }\end{array}$ \\
\hline
\end{tabular}

